\title{
Growth Performance of Pulses in Karnataka, India
}

\author{
B. Mohan Kumar ${ }^{1}$, B. S. Reddy ${ }^{2 *}$, S. B. Goudappa ${ }^{1}$, \\ Suresh S. Patil ${ }^{1}$ and G. M. Hiremath ${ }^{1}$ \\ ${ }^{1}$ Department of Agricultural Economics, UAS, Raichur, 584104, India \\ ${ }^{2}$ Agricultural Extension Education Centre, Bheemarayanagudi-585 287, India \\ *Corresponding author
}

Keywords

Growth, Pulses, Production, TMOP, Trend

Article Info

Accepted:

15 January 2020

Available Online:

10 February 2020

\section{A B S T R A C T}

Pulses are the primary source of protein for the poor and the vegetarians. Karnataka is one of the important pulse growing states in the country. The supply response of selected pulse crops were computed for a period of 41 years from 1975 to 2016 for the Karnataka state as a whole. Growth in production of total pulses increased significantly over the study period (1975-76 to 2015-16) at national level. At the national level, the growth in production of all the pulses was maximum while it was minimum in case of yield indicating contribution of area to the increase in production of pulses.At the state level the growth in production of redgram, bengalgram and total pulses increased significantly in post- TMOP mainly due to considerable increase in the area in recent years. In the case of total pulses, the growth rates in area, yield and production were positive and significant for overall period in Kalaburagi, Ballari, Karnataka and country as a whole. Among the pulses, redgram and bengalgram were the most common pulses grown in the state to meet the consumption requirement of people.

\section{Introduction}

Pulses are the primary source of protein for the poor and the vegetarians. The total pulses constitute redgram, bengalgram, greengram, blackgram, lentil and field pea. The split grains of these pulses are called dal and are excellent source of high quality protein, essential amino and fatty acids, fibers, minerals and vitamins. Pulses turn out to be one of the most economical sources of protein for human consumption and it contains 18-25 per cent of protein. These pulses improve soil health by enriching nitrogen status, long-term fertility and sustainability of the cropping systems. It meets up to 80 per cent of its nitrogen requirement from symbiotic nitrogen fixation from air, these pulses also releases substantial amount of residual nitrogen and organic matter for subsequent crops. The 
water requirement of pulses is about one-fifth of the requirement of cereals thus it saves water.

Pulses are the basic ingredient in the diets of a vast majority of the Indian population, as they provide a perfect mix of vegetarian protein component of high biological value when supplemented with cereals. The country grows a variety of pulse crops such as bengalgram, redgram, greengram, blackgram, dry peas, lentils, etc. under a wide range of agro-climate conditions. India is the largest producer and consumer of pulses in the world contributing around 25-28 per cent of the total global production. About 90 per cent of the global redgram, 75per cent of bengalgram and 37 per cent of lentil area contributed by India. (Annon., 2009).

During 2015-16, the country produced 24.78 $\mathrm{mt}$ of pulses from17.21 $\mathrm{mt}$ ha area, with an average yield of $694 \mathrm{~kg} / \mathrm{ha}$. These figures make India the largest producer of pulses in the world. With the large population dependent on pulses for protein requirements, During aforesaid period, an additional population of 350 million has been added, which led to a sharp decline in the availability of pulses from 41 grams in 1990-91 to 33 gram /capita/day in 2009-10, doubling its import (from 1.27 to 2.35 million) and resulting in skyrocketing prices. Shortfall in pulses has been attributed to a number of factors, the major ones being the increasing population, rising income, geographical shift, abrupt climatic changes, complex diseasepest syndrome, socio-economic conditions and poor marketing opportunities (Srivastava et al., 2010).

The major producers of pulses in the country are Madhya Pradesh (25\%), Uttar Pradesh (13\%), Maharashtra (12\%), Rajasthan (11\%), Andhra Pradesh (9\%) followed by Karnataka $(8 \%)$ which together share about 77 per cent of total pulse production while remaining 23 per cent is contributed by Gujarat, Chhattisgarh, Bihar, Orissa and Jharkhand. Contribution of pulses in the national food basket has reduced from 17 per cent to 7 per cent (Annon. 2015)

Karnataka is one of the important pulses growing state in the country. The total geographical area of the state is 191 lakh ha of which 123.11 lakh ha is the net cultivable area. Area under Pulses in the state has increased from 16.21lakh ha (1990-91) to 23.6lakh ha (2015-16). Similarly, the production of pulses in state has increased from 5.51 lakh tonnes during 1990-91 to 13 lakh tonnes in 2015-16. Major pulses grown in the state are redgram, bengalgram, greengram and blackgram. These four pulses account 87.93 per cent of total pulse area and 80.75 per cent of state total pulse production. It is largely grown in the northern parts of the state viz. Kalaburgi, Bidar, Yadgir, Raichur, Ballari and Vijayapura districts. Keeping this in view, an attempt is made to provide credible estimates of growth in production of pulses.

\section{Materials and Methods}

Karnataka state as a whole is purposively studied with special focus on North-Eastern Karnataka. Based on the highest area under total pulses, Bidar, Kalaburagi, Raichur and Ballari districts were selected, which are contributing 44.30 per cent of state total pulse area during 2015-16. The redgram, bengalgram, greengram, and blackgram together accounted 87.93 percent of area and 80.75 percent of state the total pulses production. Hence these four crops were selected for the study.

The present study considered for a period of 41years from 1975 to 2016 for estimating growth in area, production and productivity. 
However, for better understanding of growth and development of pulses, their growth rates in area, production and yield were compared for the period from 1975 to 2016 which was further divided in to two periods: (1) preTMOP; 1975 to 1990 (2) post-TMOP;1991 to 2016. The year 1990 was taken as a cut- off point because of introduction of programme called "Technology Mission on Oilseeds and Pulses" to promote the pulses industry in India.

\section{Compound growth rate analysis}

The linear, log-linear, exponential and power functions are some of the important functional forms employed to study the growth rates. Different functional forms were tried in the past for working out the growth rates in area, yield and production by Chengappa (1981) and Sikka et al., (1985). Some of the important forms tried were the linear growth model $(\mathrm{Y}=\mathrm{a}+\mathrm{bt})$, exponential function $(\mathrm{Y}=$ $\left.a b^{t}\right)$ and quadratic function $\left(Y=a+b t+c t^{2}\right)$. However, it was found that the exponential form of the function $Y_{t}=a b^{t}$ is the better and most frequently used one. In the present study, compound growth rates in area, production, and yield of pulses were estimated by specifying the following relationship.

$Y_{t}=a b^{t} U_{1}$

Where,

$\mathrm{Y}_{\mathrm{t}}=$ area, production and yield of pulses in year' $t^{\prime}$

$\mathrm{t}=$ year which takes value $1,2, \ldots \ldots \ldots \ldots \mathrm{n}$

$\mathrm{U}_{\mathrm{t}}=$ disturbance term in year' $\mathrm{t}^{\prime}$

' $a$ ' and ' $b$ ' are parameters to be estimated.

The equation (1.1) was transformed into loglinear form and written as:

$\log \mathrm{Y}=\log \mathrm{a}+\mathrm{t} \log \mathrm{b}+\log \mathrm{U}_{\mathrm{t}}$
Equation (1.2) was estimated by using ordinary least square (OLS) technique.

Compound growth rate (g) was then estimated by the identity given in equation (1.3).

$\hat{g}=(b-1) 100$

Where,

$\wedge$

$\mathrm{g}=$ Estimated compound growth rate in per cent per annum.

$\wedge$

$\mathrm{b}=$ Antilog of $\log \mathrm{b}$

The standard error of the growth rate was estimated and tested for its significance with ' $t$ ' statistic.

\section{Results and Discussion}

In general, a significant growth in area, yield and production of pulses was observed during the study period both at national and state levels. The demand for consumption of pulses increased over the years and also per capita consumption of pulses increased from $18 \mathrm{gms}$ in 2008 to $40 \mathrm{gms}$ in 2015-16. This might be due to consumer awareness about higher protein content of pulses and change in consumption behaviour of the consumer in one hand. The better prices, higher income with improved varieties and production technology in recent years in other hand might have encouraged the growth in pulses production in the country.

Similar results were observed for pulses by Balappa Shivaraya (1997) and Shivagangavva and Reddy (2016) respectively. At the national level, the growth in production of all the pulses was maximum while it was minimum in case of yield indicating contribution of area to the increase in production of pulses. 
At the state level the growth in production of redgram, bengalgram and total pulses increased significantly in post- TMOP mainly due to considerable increase in the area in recent years. Similar trend was observed in north Karnataka. It is worth noting that the growth in yield of most of the pulses with negative growth in pre- TMOP increased significantly in post- TMOP mainly because of intensive promotional programs launched in Karnataka including development of improved varieties/hybrids and package of practices for higher yield. Findings are in line with the results of Maikasuwa (2013), Isah Musa Ahmed et.al (2015) and Saleem and Abid (2014) wherein, growth in yield of potato, wheat and rice negative during pregreen revolution period increased significantly during post-green revolution period.

Table 1 and 2 revealed that in the case of total pulses, the growth rates in area, yield and production were positive and significant for overall period in Kalaburgi, Ballari, Karnataka and country as a whole. Districtwise estimation of growth indicated that, there was positive growth in area, production and yield in pre-TMOP in Bidar district. However, negative growth rate was noticed in post-TMOP except yield, ultimately resulted in positive growth rate in area $(0.98 \%)$, production $(1.15 \%)$ and yield $(0.90 \%)$ in the entire period. The growth rates in case of Raichur and Ballari districts were positive and significant in area, production and yield in overall period. However, growth in area, production and yield were positive and significant in all the periods except yield ($1.64 \%$ ) in Karnataka during pre-TMOP. The country as whole, growth in area $(-0.17 \%)$ was negative while it was positive both in production $(0.79 \%)$ and yield $(1.15 \%)$ during pre-TMOP. While during post-TMOP, growth in area $(0.29 \%)$, production $(1.39 \%)$ and yield $(1.11 \%)$ were positive and significant. Similar pattern of growth was observed in the overall period. The above discussed findings revealed that growth in area, yield and production during pre-TMOP was more than offset by their better growth rates in post-TMOP. Thus the growth for over all period found to be positive.

The data presented in Table 3 and 4 indicated that, among the pulses, redgram and bengalgram were the most common pulses grown in the state to meet the consumption requirement of people. Bengalgram registered higher growth in production in NEK-region as well as Karnataka as a whole mainly because of its better prices and wider market. Redgram registered second best growth in production in the state on account of its lower base on one hand and increased yields, better prices and steady demand for the produce on the other. Further improved varieties/hybrids introduced by ICRISAT, IIPR and farm universities of state, were resulted increase in production of redgram and bengalgram. This is in confirmation with the results obtained by Greshma and Bhave (2015).

A district-wise study of growth rates of selected pulses showed that area and production registered higher growth in all the selected districts in general except Raichur and Ballari in redgram and greengram crops. This is because of Bidar and Kalaburgi are the traditional pulses growing districts of the state.The growth rate in yield in all the pulses eventhough increased at all locations in postTMOP as well as for overall study period from negative growth in pre- TMOP, their growth in general found to be lower indicating the scope for improving the productivity of almost all the pulses except greengram in selected district and state. Positive growth was absorbed in pre-TMOP while negative growth was recorded in postTMOP. Similar results were observed for pulses by Shivagangavva (2016). 
Table.1 Growth rate of area, production and yield of pulses in Bidar and Kalaburgi district

\begin{tabular}{|c|c|c|c|c|c|c|c|}
\hline \multirow{3}{*}{ Crops } & \multirow{3}{*}{ Particulars } & & & & & (Per cent/a & m) \\
\hline & & \multicolumn{3}{|c|}{ Bidar } & \multicolumn{3}{|c|}{ Kalaburgi } \\
\hline & & Pre-TMOP & Post-TMOP & Over all & Pre-TMOP & Post-TMOP & Over all \\
\hline \multirow{3}{*}{ Redgram } & Area & $3.90 * * *$ & $2.56 * *$ & $2.53 * * *$ & $3.69 * * *$ & 1.43 & $1.50 * * *$ \\
\hline & Production & $4.21 *$ & $5.50 * * *$ & $5.52 * * *$ & -1.40 & $6.83 * * *$ & $2.87 * * *$ \\
\hline & Yield & 0.29 & $2.75^{*}$ & 1.04 & $-4.90 * *$ & $5.16 * * *$ & 1.28 \\
\hline \multirow{3}{*}{ Bengalgram } & Area & -10.40 & $0.86^{*}$ & 2.08 & -1.25 & 2.14 & $3.49 * * *$ \\
\hline & Production & -12.30 & 2.08 & 2.47 & -2.50 & 3.54 & $2.10 * * *$ \\
\hline & Yield & -1.49 & $2.76 * * *$ & 0.48 & -1.37 & 1.07 & 0.84 \\
\hline \multirow{3}{*}{ Greengram } & Area & 4.60 & 1.05 & $2.22 * * *$ & $10.13 * * *$ & -1.15 & $2.83 * *$ \\
\hline & Production & $4.70^{*}$ & -0.93 & 2.15 & $10.25 * * *$ & 1.52 & $4.73 * * *$ \\
\hline & Yield & 3.52 & -2.27 & -0.90 & 2.30 & 2.11 & $1.92 * * *$ \\
\hline \multirow{3}{*}{ Blackgram } & Area & $2.36 * *$ & $-3.86 * * *$ & $1.09 *$ & $5.90 * * *$ & $3.12 * *$ & $5.98 * * *$ \\
\hline & Production & 7.50 *** & -2.81 & 1.77 & 2.11 & 2.59 & $6.45 * * *$ \\
\hline & Yield & $5.07 * * *$ & -1.78 & -0.61 & -1.68 & -1.25 & -2.43 \\
\hline \multirow{3}{*}{ Total pulses } & Area & $2.85 * * *$ & -0.81 & $0.98 * * *$ & $3.76 * * *$ & $2.63 * *$ & $2.48 * * *$ \\
\hline & Production & $4.70 * * *$ & -1.39 & 1.15 & 0.33 & $6.16 * * *$ & $3.95 * * *$ \\
\hline & Yield & 1.41 & 0.30 & 0.90 & -1.93 & $3.26 * * *$ & $1.58 * * *$ \\
\hline
\end{tabular}

Note- * - Significant at 10 percent level

**-Significant at 5 percent level

***-Significant at 1 percent level 
Table. 2 Growth rates of area, production and yield of pulses in Raichur and Ballari districts

\begin{tabular}{|c|c|c|c|c|c|c|c|}
\hline \multirow[t]{2}{*}{ Crops } & \multirow{2}{*}{ Particulars } & \multicolumn{3}{|c|}{ Raichur } & \multicolumn{3}{|c|}{ Ballari } \\
\hline & & $\begin{array}{c}\text { Pre- } \\
\text { TMOP }\end{array}$ & Post-TMOP & Over all & Pre-TMOP & Post-TMOP & Over all \\
\hline \multirow{3}{*}{ Redgram } & Area & $7.85 * * *$ & 0.61 & -2.51 & $11.02 * * *$ & $-3.40 * *$ & -0.66 \\
\hline & Production & -0.87 & $3.09 *$ & $-1.85 * *$ & $7.09 * *$ & -2.50 & -1.14 \\
\hline & Yield & $-7.40 * * *$ & 1.94 & $-1.62 * *$ & $-3.00 *$ & 0.50 & -0.80 \\
\hline \multirow{3}{*}{ Bengalgram } & Area & $7.71 * * *$ & $7.92 * * *$ & $5.73 * * *$ & $-2.70 *$ & $11.80 * * *$ & $6.93 * * *$ \\
\hline & Production & 5.16 & $11.34 * * *$ & $7.37 * * *$ & $-5.20 *$ & $14.70 * * *$ & $8.37 * * *$ \\
\hline & Yield & -2.36 & 1.23 & 0.64 & $-2.50 *$ & $2.50 * * *$ & $0.35 * * *$ \\
\hline \multirow{3}{*}{ Greengram } & Area & $3.86 * * *$ & $-8.95 * * *$ & $-5.41 * * *$ & $7.50 * *$ & $-11.30 * * *$ & $-4.00 * * *$ \\
\hline & Production & $7.40 * *$ & $-11.00 * * *$ & $-8.07 * * *$ & $11.60 * * *$ & $-12.00 * * *$ & $-6.20 * * *$ \\
\hline & Yield & 3.44 & $-4.90 * *$ & $-4.03 * * *$ & $4.70 * *$ & -2.50 & -2.50 \\
\hline \multirow{3}{*}{ Blackgram } & Area & 12.44 & $-13.10 * * *$ & -4.12 & $16.80 * *$ & $-3.40 *$ & $2.64 *$ \\
\hline & Production & 9.93 & $-9.64 * *$ & -2.30 & $20.30 * *$ & -3.04 & $4.07 * * *$ \\
\hline & Yield & 23.70 & -8.60 & -0.99 & $3.50 * *$ & -1.17 & $1.80 * * *$ \\
\hline \multirow{3}{*}{ Total pulses } & Area & 1.90 & 1.25 & $1.12 *$ & 6.40 & $2.68 * * *$ & $0.74 *$ \\
\hline & Production & -0.64 & $4.47 * * *$ & 0.28 & 2.31 & $5.16 * * *$ & $2.57 * * *$ \\
\hline & Yield & $-2.77 * *$ & $3.16 * * *$ & $0.83 * *$ & -1.20 & $2.12 * * *$ & $1.22 * * *$ \\
\hline
\end{tabular}

Note- * - Significant at 10 percent level

**- Significant at 5 percent level

***- Significant at 1 percent level 
Table.3 Growth rates of area, production and productivity of pulses in NEK

(Per cent/annum)

\begin{tabular}{|c|c|c|c|c|}
\hline \multirow[t]{2}{*}{ Crops } & \multirow[t]{2}{*}{ Particulars } & \multicolumn{3}{|c|}{ NEK } \\
\hline & & Pre-TMOP & Post-TMOP & Over all \\
\hline \multirow{3}{*}{ Redgram } & Area & $4.51 * * *$ & $1.44 * *$ & $1.64 * * *$ \\
\hline & Production & 0.49 & $5.28 * * *$ & $2.42 * * *$ \\
\hline & Yield & $-3.04 * * *$ & $1.54 * *$ & -0.54 \\
\hline \multirow{3}{*}{ Bengalgram } & Area & -0.11 & $4.63 * * *$ & $4.12 * * *$ \\
\hline & Production & -1.93 & $5.97 * * *$ & $5.04 * * *$ \\
\hline & Yield & $-1.70 * *$ & $1.87 * * *$ & $0.77 * * *$ \\
\hline \multirow{3}{*}{ Greengram } & Area & $5.68 * * *$ & 0.90 & $2.63 * * *$ \\
\hline & Production & $7.73 * * *$ & 1.73 & $3.57 * * *$ \\
\hline & Yield & $3.70 *$ & -1.40 & $-1.05 * *$ \\
\hline \multirow{3}{*}{ Blackgram } & Area & $2.86 * * *$ & -1.26 & $3.10 * * *$ \\
\hline & Production & $6.44 * * *$ & -0.50 & $3.70 * * *$ \\
\hline & Yield & $3.83 * *$ & -0.32 & $1.11 * *$ \\
\hline \multirow{3}{*}{ Total pulses } & Area & $3.61 * * *$ & $2.26 * * *$ & $2.88 * * *$ \\
\hline & Production & 1.24 & $4.60 * * *$ & $3.57 * * *$ \\
\hline & Yield & -0.19 & 0.55 & 0.05 \\
\hline
\end{tabular}

Note- * - Significant at 10 percent level

**-Significant at 5 percent level

***-Significant at 1 percent level 
Table.4 Growth rates of area, production and productivity of pulses in Karnataka and India (Per cent/annum)

\begin{tabular}{|c|c|c|c|c|c|c|c|}
\hline \multirow[t]{2}{*}{ Crops } & \multirow[t]{2}{*}{ Particulars } & \multicolumn{3}{|c|}{ Karnataka } & \multicolumn{3}{|c|}{ India } \\
\hline & & Pre-TMOP & Post-TMOP & Over all & Pre-TMOP & Post-TMOP & Over all \\
\hline \multirow{3}{*}{ Redgram } & Area & $3.75 * * *$ & $2.91 * * *$ & 2.18 & $2.35 * * *$ & $0.51 * * *$ & $0.87 * * *$ \\
\hline & Production & -0.46 & $5.99 * * *$ & $2.64 * * *$ & $2.81 * * *$ & $1.00 * * *$ & $0.80 * * *$ \\
\hline & Yield & $-2.60 * *$ & $3.03 * * *$ & $0.75^{* *}$ & 0.45 & $0.51 *$ & -0.01 \\
\hline \multirow{3}{*}{ Bengalgram } & Area & $2.45 * *$ & $6.54 * * *$ & $5.25 * * *$ & $-1.61 * * *$ & $1.31 * * *$ & 0.29 \\
\hline & Production & -2.19 & 8.32 & $3.70 * * *$ & -1.36 & $2.25 * * *$ & $1.26 * * *$ \\
\hline & Yield & $-1.84 * *$ & $2.06 * * *$ & $1.64 * * *$ & 0.25 & $1.09 * * *$ & $1.03 * * *$ \\
\hline \multirow{3}{*}{ Greengram } & Area & $5.90 * * *$ & 0.85 & $2.70 * * *$ & $2.21 * * *$ & 0.16 & $0.49 * * *$ \\
\hline & Production & $6.29 * * *$ & 1.90 & $2.16^{* *}$ & $4.25 * * *$ & 0.69 & $0.91 * * *$ \\
\hline & Yield & 0.13 & $-1.80 * *$ & 0.21 & $1.99 * * *$ & 0.44 & $0.38^{*}$ \\
\hline \multirow{3}{*}{ Blackgram } & Area & $4.80 * * *$ & $-1.14 * *$ & $2.29 * * *$ & $3.43 * * *$ & 0.03 & $0.59 * * *$ \\
\hline & Production & $3.33 *$ & -1.39 & $2.96 * * *$ & $6.29 * * *$ & 0.22 & $1.46 * * *$ \\
\hline & Yield & $3.50 * * *$ & -0.66 & 0.69 & $2.76^{* * *}$ & $0.92 * * *$ & $1.18 * * *$ \\
\hline \multirow{3}{*}{ Total pulses } & Area & $2.06 * * *$ & $1.90 * * *$ & $1.50 * * *$ & -0.17 & $0.29 *$ & $0.02 *$ \\
\hline & Production & 0.36 & $3.76^{* * *}$ & $2.40 * * *$ & 0.79 & $1.39 * * *$ & $1.01 * * *$ \\
\hline & Yield & $-1.64 * *$ & $2.17 * * *$ & $1.15^{* * *}$ & $1.15^{* *}$ & $1.11 * * *$ & $1.05 * * *$ \\
\hline
\end{tabular}


The emphasis should be directed towards improving quality as well as quantity of pulses productivity in coming years to meet the increasing demand in view of limitation of cultivable land. Therefore, there is need to formulate crop specific policies to increase pulse production in general and blackgram in particular at the state and national level.

Conclusion of the study is as follows:

Growth in production of total pulses increased significantly over the study period (1975-76 to 2015-16) in Bidar, Gulbarga, NEK region, Karnataka and national level except Raichur and Ballari districts, wherein negative growth in production was noticed in redgram, greengram and blackgram. The district-wise study of growth rates of selected pulses showed that area and production registered high growth in all the selected districts in general except Raichur in redgram and Ballari greengram and blackgram crops. Among the pulses, bengalgram registered higher growth in production in north eastern Karnataka as well as Karnataka as a whole. While Redgram registered second best growth in production in the state. Therefore, there is need to formulate area stabilizing policies such as introduction of new verities, resistance to pest and disease, special schemes on supply of subsidised inputs, increase in MSP, etc.

\section{References}

Anonymous, 2015. Vision 2030., 2016, Indian Institute of Pulse Research report, Kanpur. Pp. 11-15.
Balappa Shivaraya, 1997. Production, marketing and processing of redgram in Gulbarga district -An economic analysis. M. Sc. (Agri.) Thesis, University of Agricultural Sciences. Dharwad.

Chengappa, P.G., 1981. Growth rates of area, production and productivity of coffee in India. Journal of coffee research, 11(4): 19-26.

Greeshma, R. and Bhave, M.H.V., 2015. Growth trends of sugarcane (Saccharum officinarum) crop in Telangana. The J. Res. PJTSAU, 42(3):84-86.

Isah Musa Ahmad, Samuel E., Makama S.A. and Kiresur V.R., 2015. Trend of area, production and productivity of major cereals: India and Nigeria scenario. Res. J. Agric. and Forestry Sci., 3(2), 10-15.

Maikasuwa, M., A., 2013.Trend analysis of area and productivity of sorghum in Sokoto state, Nigeria. European Scientific J., 9(16) 1857 - 7881.

Saleem and Abid, 2014. Growth trend in area, production and yield of major crops of Khyber Pakhtunkhwa, Pakistan. Asian J. of Agric. and Rural Development, 4(2): 149-155.

Shivagangavva, P.D., and Reddy, B.S., 2016. Growth in demand and supply of pulses in India-A normative approach. $J$. of Applied and Natural Science, 8(4): 1756-1761.

Sikka, B.K. and Vaidya, C.S., 1985. Growth rates and cropping pattern changes in agricultural in Himachal Pradesh. Agricultural Situation in India, 39 (11): 843-846.

\section{How to cite this article:}

Mohan Kumar, B., B. S. Reddy, S. B. Goudappa, Suresh S. Patil and Hiremath, G. M. 2020. Growth Performance of Pulses in Karnataka, India. Int.J.Curr.Microbiol.App.Sci. 9(02): 22722280. doi: https://doi.org/10.20546/ijcmas.2020.902.257 